\title{
Vietnamese Universities and Regional Accreditation in the United States
}

\author{
Jonathan Lankford ${ }^{1, *}$ \\ ${ }^{1}$ American College of Education
}

\begin{abstract}
Vietnamese and other Southeast Asian universities view the importance of national accreditation secondary to international recognition. As a result, Southeast Asian regional accreditors are expanding their university networks and forming international standard education in Southeast Asia. However, the link between Asian and American accreditation has yet to be formed, even though America is the number one education destination for international students. The research paper that this proposal intends to put forth will evaluate the differences in Asian and American regional accreditation; it will highlight potential academic, institutional, and cultural issues that may arise when a Vietnamese university seeks American regional accreditation.
\end{abstract}

DOI: https://doi.org/10.53901/qzym3ww605k

\author{
KEYWORDS \\ Vietnamese \\ Universities \\ Regional Accreditation
}

ARTICLE HISTORY

Received: 15.08 .2020

Accepted: 15.09 .2020

Online: 01.10 .2020

\section{VIETNAMESE UNIVERSITIES AND REGIONAL ACCREDI- TATION IN THE UNITED STATES}

Vietnamese and other Southeast Asian universities view the importance of national accreditation secondary to international recognition [1]. As a result, Southeast Asian regional accreditors are expanding their university networks and forming international standard education in Southeast Asia. However, the link between Asian and American accreditation has yet to be formed, even though America is the number one education destination for international students [2]. The research paper that this proposal intends to put forth will evaluate the differences in Asian and American regional accreditation; it will highlight potential academic, institutional, and cultural issues that may arise when a Vietnamese university seeks American regional accreditation.

\section{PROBLEM STATEMENT AND PURPOSE}

The question of quality has plagued Vietnamese higher education for years. Vietnam's Ministry of Education and Training (MOET) established a national accreditation board in 2003 [3], and Vietnamese universities began to implement standards by 2005 [4]. However, institutions have opted to circumvent national accreditation to pursue international recognition in Europe and other parts of Asia [1]. For example, ASEAN University Network (AUN), one of the larger regional accreditors in Southeast Asia (SEA), lists 30 accredited institutions from ten countries in SEA, three of those institutions being from Vietnam [5]. The national accreditation system in Vietnam has had limited success implementing and tracking quality assurance in higher education. This has been due in part to the fact that the national accreditation centers are publicly operated out of the national university, an obvious conflict of interest [6]. Other reasons include the fact that accreditation appears to be micro-managed under state control [7] and does not seem to adequately measure improvements in modern teaching methodology, such as student-centered learning [8]. Further and current research of the internationalization of Vietnamese higher education will not only benefit Vietnamese constituents, but also education globally. Research can establish best practices for those institutions whose goal is international accreditation and highlight potential problems that may arise when Vietnamese universities pursue recognition from American regional accreditors. The research will benefit higher education systems across Asia that face similar challenges to those in Vietnam. Accreditors can review the research to better support universities in their road to international recognition.

\section{LITERATURE REVIEW}

Knowledge of the quality assurance models currently in use in Asia is essential for the completion of the proposed research. The information provided by SEAMEO RIHED [9] and Miyahara [10], though dated several years prior, has significant historical and present value. They conducted a regional survey to investigate 
and compare various Southeast Asian quality assurance models with the intent to aid in the development of a unified quality assurance system for the whole region. SHARE [11] organized and detailed the quality assurance models by country, while Fahmi [12] wrote a cursory overview with more recent information regarding Southeast Asian quality assurance models. Knowledge of the national education systems in Vietnam and other Southeast Asian countries is also essential for the completion of the proposed research. Lee [13] and Sugimura [14] conducted a literature review and reported on the types and functions of university cooperation as a means for internationalization. International cooperation can lead to improved alignment to the partner universities' curriculum that meet accreditation standards at the program level. A cursory initial search for information regarding Vietnam's national accreditation system returned several research articles that provide information garnered through conducting literature reviews, case studies, and professional interviews [7]. Published news reports give commentary on Vietnamese university accreditation [15].

\section{METHODOLOGY}

After a thorough search for digitally available information, I intend to make a thorough comparison of American regional accreditors and Southeast Asian accreditors, specifically regarding their information from instructional manuals, standards, and work samples. This may immediately reveal significant differences in expectations from the various accreditors. After that, I will attempt to attend physical or online workshops and seminars on regional accreditation in the U.S. and in Southeast Asia. I will collect selfassessment documentation from Vietnamese universities and have it translated into English to identify potential issues regarding differences in procedures and documentation. After having the appropriate knowledge of the research topic so that I can identify and develop data collection tools, I will collect original data from Vietnamese universities related to accreditation and making a path to American regional accreditation.

\section{RESULTS AND DISCUSSION}

The research paper will map out onto matrices key similarities and differences in accreditation instructions, standards, and work samples. It will also show a progressive trend in various aspects of quality assurance in Vietnam. It will list data collected from Vietnamese universities regarding potential issues with a path to American regional accreditation. Factors will not only include academic programs or institutional procedures, but also cultural ideologies and potential operating conflicts. This and opinion data will be displayed quantitatively in appropriate categories, with groups and subgroups, with an accompanying qualitative analysis.

\section{CONCLUSION}

Apparent conflicts in how academic programs develop and the operations of government oversight seem to be factors that hinder American accreditation. Even so, Vietnamese universities have opted out of national accreditation to become internationally recognized by various other higher education institutions in Asia and Europe. The prime international education destination for Vietnamese students remains the U.S., yet no Vietnamese universities seem to be on the road to American regional accreditation. This research paper will evaluate the changes that Vietnamese universities may need to implement, present key issues to avoid or resolve, and draw a map to American accreditation.

\section{REFERENCES}

[1] Vietnamese universities reject results of domestic accreditation centers. VietNamNet, Dec 2017.

[2] Top 20 countries for international students. www.theguardian.com, Jul 2014.

[3] Kim Nguyen, Diane Oliver, and Lynn Priddy. Criteria for accreditation in vietnam's higher education: Focus on input or outcome? Quality in Higher Education, 15:123-134, 072009.

[4] H.C. Nguyen. An evaluation of the impacts of accreditation on vietnamese universities, July 2014.

[5] Aun member universities, 2012.

[6] Cuong Nguyen, Colin Evers, and Stephen Marshall. Accreditation of viet nam's higher education: Achievements and challenges after a dozen years of development. Quality Assurance in Education, 25:475-488, 072017.

[7] Meggan Madden. Walking the line: quality assurance policy development and implementation in vit nam. Higher Education, 67(1SN - 1573-174X):91-104, Jan 2014.

[8] Nga D. Tran, Thanh T. Nguyen, and My T.N. Nguyen. The standard of quality for heis in vietnam: a step in the right direction? Quality Assurance in Education, 19(2):130-140, Apr 2011.

[9] Southeast Asian Ministers of Education Organisation Regional Centre for Higher Education and Development. A study on quality assurance models in southeast asia: Towards a southeast asian quality assurance framework. 2012.

[10] Shizuko Miyahara. Regional Quality Assurance System for Higher Education in Southeast Asia, pages 25-38. Springer New York, New York, NY, 2015.

[11] Indonesia: SHARE Project Jakarta. Higher education quality assurance in the asean region: State of affairs and development needs.

[12] Z. M. Fahmi. Development in asean: Asean regional quality assurance framework and asean higher education common space, July 2017.

[13] Lee Molly N.N. Regional cooperation in higher education in asia and the pacific. Asian Education and Development Studies, 1(1):18-23, Jan 2012.

[14] Miki Sugimura. Possibility of east asian integration through the regional networks and universities' cooperation in higher education. Asian Education and Development Studies, 1(1):85-95, Jan 2012.

[15] Vietnam's second university gains aun-qa accreditation. Nhan Dan, Jan 2018. 